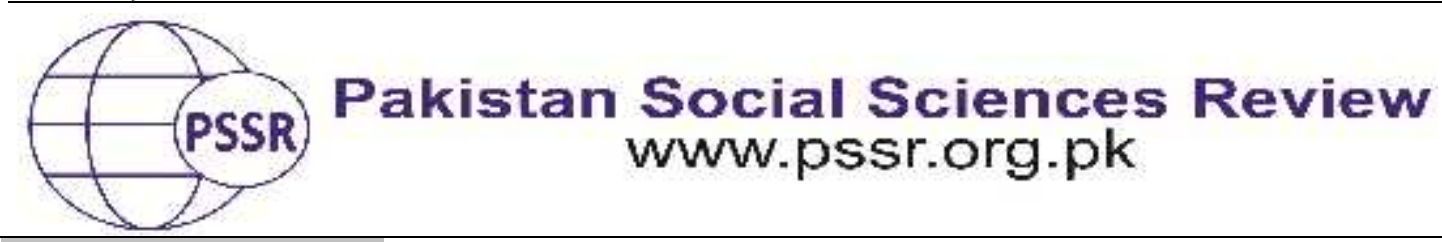

RESEARCH PAPER

\title{
A Fundamental Rights Perspective of Land Reforms in Pakistan
}

Dr. Ghufran Ahmed ${ }^{1}$ Dr. Ataullah Khan Mahmood ${ }^{2}$ Dr. Saqib Jawad ${ }^{3}$

1. Visiting Faculty Member, Department of Law, Faculty of Shariah \& Law, International Islamic University Islamabad, Pakistan

2. Assistant Professor, Department of Law, Faculty of Shariah \& Law, International Islamic University Islamabad, Pakistan

3. Civil Judge cum Judicial Magistrate, Islamabad, Pakistan

\begin{tabular}{|c|c|}
\hline PAPER INFO & IBSTRACT \\
\hline & \multirow{6}{*}{$\begin{array}{l}\text { This paper analyses whether the constitutional rights and } \\
\text { freedoms available to the citizens of Pakistan can be realized for } \\
\text { the agricultural tenants without introducing large scale land } \\
\text { reforms including the fixation of a ceiling on individual land- } \\
\text { holdings in Pakistan. The landlords owning large areas of land } \\
\text { do not directly till the soil. Rather, the landless tenants and other } \\
\text { seasonal labourers till such soil to get their livelihood. A critical } \\
\text { and analytical study of the relationship between such landlords } \\
\text { and tenants is made in this paper. This analysis reveals that the } \\
\text { utter dependence of the tenants on landlords result in } \\
\text { oppressive exploitation of the former by the latter. }\end{array}$} \\
\hline & \\
\hline & \\
\hline & \\
\hline & \\
\hline ponding & \\
\hline Author & $\begin{array}{l}\text { Consequently, it is found that the violation of a number of } \\
\text { fundamental rights and freedoms provided to the citizens of }\end{array}$ \\
\hline orne & ur. There is urgent need of \\
\hline
\end{tabular}

\section{Introduction}

The Shariat Appellate Bench of the Supreme Court (SAB) in Qazalbash Waqf case (Supreme Court [SC] 1990) has held, inter alia, the fixation of a ceiling on individual land-holdings repugnant to the injunctions of Islam. Thus, various provisions of the Land Reforms Regulation, 1972 (M.L.R. 115 of 1972) and the Land Reforms Act, 1977 (Federal Act II of 1977) were declared null and void. This has practically put an end to any land reform efforts in Pakistan. However, it should be noted that without fixation of such ceiling, a number of social evils and violations of the fundamental rights of the agricultural tenants and labourers attached to the land cannot be properly redressed. Moreover, such social evils and violations do not conform to the fundamental rights, freedoms and liberties and the principles of policy provided in the Constitution of the Islamic Republic of Pakistan (the Constitution). 
It is argued that the exploitation of the tenants, the forced labour which the tenants have to bear, their undignified treatment, waste of natural resources, violation of rights and freedoms of assembly, speech and association inherent in the institution of landlordism are a total negation of the egalitarian society which the people of Pakistan want to create. This paper, therefore, presents a detailed analysis of the rights and protections available to the citizens of Pakistan including, of course, the poor attached to the land under the Constitution as held by the superior courts of the country.

Nonetheless, the miserable plight of the agricultural tenants and labourers is briefly highlighted before proceeding further. This has been pointed out by almost every author who has penned upon the institution of landlordism. Thus, many historians who have studied land tenure of the British India bitterly criticized this institution. However, only a few such documents are discussed here. These documents include the Sind Hari Enquiry Committee: Minute of Dissent by M. Masud (1949), Report of the Agrarian Committee of the Pakistan Muslim League [RAC] (1949), The First Five Year Plan [FYP] (1955-60) and the Report of the Land Reforms Commission for West Pakistan [RLRC] (1959).

It is worth mentioning that the land reforms are a topic more of agroeconomics than that of law. However, after the judgment of the SAB in the Qazalbash Waqf case referred above, a lot has been written on the Islamic perspective of the land reforms. But anything on the fundamental rights perspective of such reforms can be hardly found. This paper, therefore, explores the fundamental rights perspective of the land reforms in Pakistan.

The Land Reforms Commission for West Pakistan was formed "to recommend measures to ensure better production and social justice as well as security of tenure for those engaged in cultivation"(RLRC, 1959, as cited in ed. Nawab Haider et al, 1987, p. 161).Similarly, the First Five-Year Plan (1955-60) of Pakistan devoted a complete chapter to this issue. The importance of land reforms was emphatically stressed in Chapter 17 of this plan in the following words:

For under-developed countries land poses the most perplexing problem in view of its scarcity combined with its major role in the achievement of a richer and higher life for the majority of the people. However, the pattern of agrarian structure which will best subserve the needs of a developing society has come clearly into view and reforms can only be delayed but not prevented (FYP, 1955-60, as cited in ed. Nawab Haider et al, 1987, p. 141, underlining is mine).

The dissenting note of Masud impressed the public particularly the young workers of the then Muslim League to such an extent that pursuant to their demands the Muslim League Council passed a Land Reform Resolution in 1950. 


\section{The Institution of Landlordism and Social Evils}

The exploitation of the cultivator is a dominant basis of the landlordism and the feudalism. According to the dissenting note of Masud, the haris (agricultural tenants) do not have any security of tenure in the land they have been cultivating for generations. They are, in fact, at the mercy of the landlords for their food and living. Consequently, the former fully exploit the latter. The majority report generally while the note of dissent in particular fully takes the notice of this exploitation. Thus, it points out that the haris are harassed by the landlords and their agents to an extent that they voluntarily abandon their rights (Masud, 1949).

Similarly, it is a common practice to observe that the haris toil the soil the whole season and when the crop is ready for harvesting, the agents of the landlords require the haris to carry the harvested crop to the threshold of the landlords. Customarily, this crop is to be shared equally between the haris and the landlords. But actually the haris get only a minor share since their share bears charges and encumbrances imposed by the landlords. This minor share does not even fulfill their food needs. The author of the note draws the picture of the hari in these words, “...He is thus like a hungry man who, having secured food after long toil and suffering, has to surrender it to his cruel master who takes away a large part of it, leaving the hungry man only a small portion which does not suffice for his empty stomach" (Masud, 1949, p. 33).

Likewise, in other parts of Pakistan the observations of the Agrarian Committee concerning the same exploitation are worth mentioning here. The report reads:

...the nominal division of share between the landlord and the tenant very rarely represents the real share which falls to the tenant. For apart from the legal dues of the landlord, there are in most cases... of the West Punjab and Bahawalpur a variety of legally unjustified dues and services which are sanctioned by custom and enforced by the superior bargaining power of the landlord. These dues and services are extremely oppressive... (RAC, 1949, as cited in ed. Nawab Haider et al, 1987, p. 105-106).

Not only the tenants are deprived of their due share in the crops but they also have to indulge themselves in unpaid labour against their free will. For their survival, they are available to any call by the zamindar day in and day out. This form of forced labour has been described in the following words:

The zamindarmight at any time send for the harifor begar(forced labour) for the construction of his house or the sinking of a well, or some other minor work. He might be called to come with his plough and bullocks to cultivate the private fields of the zamindaror to spend a few days on a shoot with him, or to render some domestic service. He is thus always at the beck and call of the zamindar, and dare not refuse him as that could spell his doom(Masud, 1949, p. 60). 
The above mentioned treatment of the tenants by the landlords has not only caused damage to the tenants and their families only but also to the whole nation. The tenants because of their cruel treatment work half-heartedly; this directly affects the production of the land. Moreover, the haris cannot even greet the landlords in an ordinary manner nor can they sit at the same level on which the landlords sit. Usually they bow before the landlords and touch their feet not out of respect but because of their complete dependence on the land held by the latter.

Yet another violation of the fundamental rights of haris is concerned with the right of association. They cannot vote with their free will. Rather, they are forced to vote only for the candidate supported by the landlord under whom the haris cultivate the land. The haris are under so much pressure from the landlord during the elections that they do not even hesitate to take the Holy Quran in their hands to assure the latter of their allegiance.

Considering the miserable plight of the poor attached to the land, the report of the Agrarian Committee recommends for a direct interest in land for every village labourer. The report reads:

it is only when every agricultural labourer has acquired a direct interest in land, and every village artisan is a dignified and prosperous member of emancipated village community regulated by the State, that agrarian economy will be released from its present degradations and the lowest strata of our population will be freed from their servitude (RAC, 1949, as cited in ed. Nawab Haider et al, 1987, p. 122).

Similarly, the Report of the Land Reforms Commission referred above acknowledges, "Those who do not own land are relegated to a socially inferior position with all the disabilities of that position" (RLRC, 1959, as cited in ed. Nawab Haider et al, 1987, p. 167-168).

One should not be mistaken that the exploitation of the agricultural tenants and other depressed classes of the village community at the hands of landlords and feudal lords was a past history. This can be witnessed even recently. In this regard, the observations of the Federal Shariat Court(FSC) in Syed Shabbir Hussain Kazmi case are worth mentioning here (Federal Shariat Court [FSC] 2006. The FSC first observes that the Bonded Labour System (Abolition) Act, 1992 is a beneficial legislation aimed at providing relief against the forced and bonded labour to all the workers belonging to the depressed classes of the society including the haris, tenants-at-will and other such people.Nonetheless, the object for which the above mentioned Act was enacted could not be effectively achieved. In this regard, the FSC points out different news published in the national newspapers telling about the unlawful detention of the labourers for extracting forced labour from them throughout the country.

In contrast to the institution of landlordism and feudalism, the most desired objectives behind land reforms are to increase the productivity of land, make agricultural a more economic and profitable business, improve the economic and social status of those involved in this vocation and so on. In 1970s many rulers and 
governments were inspired by socialism. Therefore, a very important aspect of such reforms introduced in Pakistan was redistributive reforms i.e. taking land from big landlords and redistributing the same among the tenants. Nonetheless, the basic principle on which land reforms are carried out is that the benefits from land should go to the actual tillers of the soil.

\section{Fundamental Rights and the Constitutional Courts}

The fundamental rights jurisprudence is very rich in Pakistan. It is discussed and analyzed with reference to the behavior and remarks of the constitutional courts of Pakistan while adjudicating the fundamental rights issues. Thus, the apex court of the country in Abdul Wahab case emphasized the significance and importance which the Constitution has granted to the fundamental rights in very strong words (SC, 2013). According to the Court, the fundamental rights have no parallel and the State with all its institutions is bound to protect and enforce these rights at every level.

With respect to the interpretation and scope of the fundamental rights, the apex court in Mian Muhammad Nawaz Sharif case held that the scope of the fundamental rights is ever changing(SC,1993). It broadens and widens with the progress of the society. The fundamental rights provided by the constitutions of the modern world have a long history and can be traced to have their origin in natural law. Since a lot of development has been made in political, social and economic fields, these rights need to be interpreted widely. In fact, the courts are under a duty to protect and enforce these rights keeping in view the changed social needs having a progressive and futuristic approach.

Similarly, the Lahore High Court in Shaheen Cotton Mills case explained a very useful rule of interpretation of the constitutional provisions (Lahore High Court [LHC], 2011). The Court remarked that the Constitution is a living document. Therefore, the social and economic needs of people and the emerging developments in the society must be borne in mind while interpreting its provisions. Consequently, the interpretation by the courts of law should be such as to embrace all these aspects.

\section{Importance of the Principles of Policy and their Relation with the Fundamental Rights}

The constitutional courts of Pakistan have given great importance to the principles of policy while interpreting and enforcing the fundamental rights. The Supreme Court, therefore, in Miss Benazir Bhutto case elucidated the significance of these principles authoritatively (SC, 1988). The placement of these principles next to the fundamental rights in the same part of the Constitution suggests that the former are supposed to operate within the framework of the latter. The Court terms the fundamental rights and the principles of policy collectively as the "conscience of the Constitution"(SC, 1988, p. 510). 
The apex court in this case also interpreted the intention of the makers of the Constitution with respect to the practical relation of the fundamental rights and the principles of policy. The goal of the egalitarian society which the people of Pakistan want to achieve can only be attained when the provisions contained in the two chapters of the Part II are woven in the same net. The Court clarified that, "...the authors of the Constitution, by enumerating the Fundamental Rights and the Principles of Policy, apparently did so in the belief that the proper and rational synthesis of the provisions of the two parts would lead to the establishment of an egalitarian society under the rule of law..." (SC, 1988, p. 510).

Similarly, a Division Bench of the Sindh High Court in Shah Murad Sugar Mills case emphasized the importance of the principles of policy provided in Part II of the Constitution(Sindh High Court [SHC], 2003). The Court held that these principles can always be called in aid for the interpretation of the rest of the constitutional provisions. Moreover, the Court determined that the interpretation which promotes the objectives stated in these principles is to be adhered to.

That is why; the Peshawar High Court in Mst. Margrate case disapproved the act of the education department of refusing the payment of salary to the employee in spite of her rendering services to the department (Peshawar High Court [PHC], 2005). The Court held that the act of stopping the salary of the employee is against the principles of policy. Emphasizing the importance of the principles of policy, the Court observed that it is the duty of every department of the State to act in accordance with the principles of policy so far as they relate to that department. The Court further observed that the act of the department amounted to forced labour which is prohibited under article 11 of the Constitution. The Court explaining the duty of the education department also referred to article 29 which enjoins upon all the institutions of the State to act in conformity with the principles of policy.

Likewise, a Division Bench of the Lahore High Court in Qazi Akhtar Ali case ordered the payment of salary to the petitioner(LHC, 2000). In fact, in this case fifteen days' salary was refused to a secretary of the Market Committee, a corporate body established under the Punjab Agriculture Produce Markets Ordinance, 1978. The Court while ordering the payment of salary held that services without pay not only amount to forced labour but it also amounts to the violation of the principles of Islam and social justice as contained in the principles of policy provided in chapter 2 of Part II of the Constitution. Thus, the Court held that the violation of the principles of policy is deplorable.

As far as the issue whether the principles of policy are enforceable and justiciable is concerned, the apex court in Miss Benazir Bhutto case remarked that the principles of social and economic justice as provided by the principles of policy though have not been made directly justiciable, the same are the basis and guidelines of all the legislative and executive actions of the State institutions (SC, 1988). It was held that these provisions are indirectly enforceable and the enforcement of the same is essential for the democratic momentum of the State. Likewise, the Sindh High Court in the Shah Murad case referred above acknowledged that though the 
principles of policy are not directly justiciable, the superior courts of the country have very often sought help from these principles while enforcing the fundamental rights (SHC, 2003).

\section{Other Constitutional Provisions that Work within the Framework of the Fundamental Rights}

Besides the fundamental rights and the principles of policy, there are some other constitutional provisions which operate within the framework of these rights and principles. The most notable among these provisions, for the purposes of the present research, are articles $2 \mathrm{~A}$ and 3 of the Constitution. The former has made the principles and provisions contained in the Objectives Resolution a substantive part of the Constitution while the latter enjoins upon the State to eliminate all forms of exploitation. It also requires the State to strive for "the fundamental principle, from each according to his ability to each according to his work" (the Constitution, 1973). Thus, it will be observed in the following lines that the superior courts while interpreting the fundamental rights and the principles of policy make a frequent reference to these articles.

Apart from the cases discussed above where the courts have disapproved the act of getting services without payment of wages relying on the prevention of forced labour and the principles of policy, the courts have also disapproved the same referring to the elimination of exploitation, right to life and dignity of man. Thus, in Zahid Ahmed case a Division Bench of the Sindh High Court held that the services of a person without paying him his due salary is not only forbidden as forced labour but it also amounts to exploitation which is forbidden under article 3 of the Constitution(SHC, 2012). The Court even called it a violation of right to life. Though the Court termed it the violation of the above mentioned fundamental rights, there is no reason why it should not be declared against the dignity of man, hence a violation of article 14 as well.

Similarly, the Lahore High Court in Abdul Qadir case ordered the payment of salary to a class IV employee of the education department who had rendered services for three years though his appointment had not been verified by the chairman (LHC, 2001). The Court held that services without the payment of salary or wages amount to slavery which is prohibited by the Constitution. Moreover, services without legal consideration were pointed as the practice of the primitive ages when the rulers used to treat their subjects as their slaves or the wealthy used to-treat the weak cruelly (LHC, 2001).

Widening the scope of exploitation to include uncertainty in it, the Sindh High Court in Ayaz Ahmed Memon case observed that it is against the requirements of article 3 that a person should work in a state of uncertainty. The fear that he can lose his livelihood at any time is the worst form of exploitation(SHC, 2011).

\section{Special Protection for Backward and Depressed Classes}


The courts have hardly tolerated any violation of the rights of the underdeveloped people like the tenants and haris and other agricultural labourers. Thus,the Supreme Court in the Human Rights Commission of Pakistan case reversed the judgment of the Sindh High Court and ordered the release of the tenants who had been detained by the landlords and were compelled to engage themselves in forced labour (SC, 2009). The facts of this case demonstrate how the institution of landlordism is violating the fundamental rights of the tenants and other agricultural labourers even recently.

The zamindars restricted the free movement of the tenants and subjected them to forced labour on the pretext of the loans the former had advanced to the latter. This constituted a clear violation of not only the Bonded Labour System (Abolition) Act, 1992 but also thearticle 15 of the Constitution which provides for the freedom of movement.

With respect to the application of the Bonded Labour System (Abolition) Act, 1992 to the tenants and other agricultural labourers, the Court held that the relationship of tenants and landlords is governed by the provisions of the Sindh Tenancy Act, 1950 as long as this relationship continues. However, once this relation comes to an end, the provisions of the Bonded Labour System (Abolition) Act, 1992 come into play even with respect to those transactions which were made in the previous relationship of landlord and tenant. While with respect to other agricultural labourers, the provisions of the 1992 Act apply absolutely and the provisions of the 1950 Act are not applicable.

The Court feels no hesitation in acknowledging the evils of the institution of the landlordism but is constrained to express its views on this issue due to the technicalities of the judicial system. Paragraph No. 5 of the judgment is a clear evidence of this fact.

Moreover, the superior courts have also taken the notice of the disparity between the bargaining strength of the parties and have always sided with the depressed and disadvantageous classes more particularly when the matter involves the protection and enforcement of the fundamental rights. This is evident from the judgment of the Supreme Court in Ikram Bari case(SC, 2005). One of the issues before the Court for determination in this case was the regularization of the bank employees, particular the minor staff. The Court declared that a society free from exploitation and providing social and economic justice to its inhabitants is required to be set up in an Islamic welfare State.

On the basis of the above observations, the Court held that the disparity between the employer and the employee and disequilibrium between their bargaining strength will not be allowed to play any role in transactions and dealings between them. In this regard, the Court also made an express reference to article 38 which provides for the social and economic well-being of the people and requires the State to formulate policies, inter alia, for the equitable adjustment of rights between employers and employees, and landlords and tenants. 
Similarly, the Lahore High Court in Umer Rathore case while exercising jurisdiction under Article 199 of the Constitution held section 15 of the Financial Institutions (Recovery of Finances) Ordinance 2001 ultra vires of the Constitution on a number of grounds (LHC, 2009). However, for the purposes of the present discussion, the most relevant ground was the obvious difference between the positions of the litigants, the financial institution and the borrower. The Court held that where parties are not equally placed and one of the parties has advantageous position over the other their dealings may violate articles $2 \mathrm{~A}, 3,4,9,18,23,24$ and 25 of the Constitution.

Similarly, a seven member bench of the Supreme Court in Arshad Mehmood casedisapproved the exploitation of the weaker classes of the society in all forms (SC, 2005). In this case, Section69-A of the Punjab Motor Vehicles Ordinance, 1965 was declared ultra vires of the Constitution being exploitative, imposing unreasonable restrictions on lawful occupation of transport and against the mandate of article 38 which requires the State to form policies and take actions for the promotion of social and economic well-being of the people.

In another case, the Lahore High Court observed that the weak bargaining position of a particular group of people must not operate as a tool for the compromise of their fundamental rights and protections provided to them by the Constitution (LHC, 1997). The Court criticised the unbridled laissez faire while determining the issue of regularization of service of an employee. The Court said that it is against the constitutional protections provided to the citizens that the employer may exploit the employees due to the weak bargaining position of the latter. Since the Constitution prohibits the exploitation and provides for the dignity of man, the rule of hire and fire as practiced by the colonial masters in the preindependence era cannot be allowed to continue.

\section{Protection and Preservation of Natural and National Resources}

The constitutional courts have been very cautious about their response with respect to the protection and preservation of natural resources and the national wealth of the State. The Supreme Court in the Alleged Corruption in the Rental Power Plants case, in the very opening paragraph of its judgment made a reference to article 2A and observed that Pakistan is to be governed by the chosen representatives of the people under the Constitution (SC, 2012). Such representatives are, therefore, required to govern the State being faithful to the people of Pakistan, honestly and to the best of their abilities which definitely includes taking all steps for the well-being and the prosperity of the people of Pakistan.

The well-being of the people referred above is none other than the social and economic well-being. In this regard, the Court made reference to the principles of policy and the Objectives Resolution to clarify that the government is bound to take steps for the welfare of the people. The Court said, "It is to be clarified that the Government of the day under Article 29 read with Article 2A of the Constitution is 
bound to formulate policies for the promotion of social and economic well-being of the people..." (SC, 2012, Paragraph 15).

Land is one of the most important natural resources available to a State to fulfill the living needs of its population. Thus, its proper distribution and utilization can play a pivotal role in the well-being and prosperity of the people. The Supreme Court in the above mentioned case took particular note of the preservation of the natural resources for the well-being and prosperity of the people. The Court emphasizing the obligations of the elected government with respect to the preservation and protection of the natural resources held the same one of the constitutional duties of the government towards its citizens. The Court determined that these resources fall within the definition of property and made an express reference to article 24 which provides for the protection of property rights.

Likewise, the Supreme Court in Muhammad Yasin case while holding the appointment of the chairman OGRA null and void ruled that "the Constitution envisages a political dispensation where good economic governance is a right of the people of Pakistan which they cannot be deprived of" (SC, 2012, Paragraph 13). The Court explained that the Constitution is to be interpreted as an integrated whole and if the Constitution is looked in this manner, it becomes absolutely clear that the Constitution fully protects the economic well-being of the people.

It requires the State and the government to be vigilant about the resources of the State. Any negligence on the part of the government with respect to the protection of the State's resources will be considered a violation of the fundamental rights of the people. Moreover, the Supreme Court held the same view about the national wealth/resources in another case where it had to determine the scope of the powers of a caretaker government (SC, 2013).

Similarly, the scope of article 9 was discussed by the Supreme Court in Shehla Zia case while determining the alleged violations of the fundamental rights due to the installation of a grid station close to the residential area (SC, 1994). The Court held that the right to life cannot be restricted to mere vegetative life rather it covers all facets of life. Thus, the word life as used in article 9 is not to be construed narrowly but it includes the right to enjoy life as well. Moreover, the Court also made a reference to article 14 which talks about the dignity of man. The Court raised a very vital question which emerges by the combined reading of both these articles. The Court interrogated whether the fundamental rights provided by these articles can be said to be fully enjoyed if the people live miserable lives without having even bare necessities such as food, clothing etc.

\section{Protection and Promotion of Democratic Values}

The right to vote and form a government of the representatives is the essence of democracy and fully protected under the various constitutional provisions. The constitutional courts have reiterated this principle time and again in their judgments. However, the institution of landlordism, as noted above, has been responsible for the 
violation of this fundamental right of the tenants and other agricultural labourers working under them.

The Supreme Court has been very watchful in enforcing every aspect of this fundamental right.

Thus, the apex court in Mian Muhammad Nawaz Sharif case emphasized the protection given to it by the Constitution. It was held, “...In a democratic just order every citizen has right to equal participation in the political process as required by the Constitution. Every citizen without any discrimination within the frontiers of the Constitution can profess, practise, exercise and operate his right to participate in the governance of the country..."(SC, 1993, p. 824). Saad Saood Jan J. agreeing with the majority opinion further explained, "...There seems little doubt that the paramount consideration before the Constitution makers was that no section of the citizenry no matter how small it might be should be deprived of equal participation in the national life and no one should feel that he has not had a fair deal..." (SC, 1993, p. $675)$.

In this regard, the apex court in Workers' Party Pakistan case had to adjudicate, inter alia, whether the prevailing electioneering practices involving wealth, power and influence are against the mandate of the Constitution regarding free, fair, just and honest elections on a level playing field (SC, 2012). The Court, in order to answer this question, explained the scope of article 17 of the Constitution which generally provides for the freedom of association. The Court held that under this provision it is a fundamental right of the citizens "to partake in the political governance of the State" (SC, 2012, Paragraph 37). The freedom of association as provided by this article includes freedom of assembly as well as freedom of speech as provided by articles 16 and 19 respectively.

Democracy is a salient feature of the Constitution and the same is realized through elections. The constitutional mandate for holding/conducting elections is that the same should be free, fair and transparent. Therefore, a voter should be facilitated "to exercise his right of franchise independently with full application of mind and without influence from the candidate or his supporters" (SC, 2012, Paragraph 52).

The Court answered the above referred question in affirmative and held that the election campaign should be in reach of a common man. Regarding the election campaign, the Court said, "Only such election campaign activities ought to be permitted, which on the one hand fulfill the purpose of the election campaign, and on the other are within the reach of the common man..."(SC, 2012, Paragraph $80(1)(\mathrm{g}))$.

Similarly, the Supreme Court in its judgment in Imran Khan case ordered the preparation of correct and complete electoral rolls and explained that such preparation was a sine qua non for the free, fair and transparent elections which is a 
mandatory constitutional mandate (SC, 2013). However, the miserable conditions of the depressed classes under the institution of landlordism and their status does not allow them to exercise their fundamental right as provided under article 17 of the Constitution.

Given the importance of this right, the amendments made in the Political Parties Act, 1962 and the Freedom of Association Order, 1978 were challenged in Benazir Bhutto case before the Supreme Court being inconsistent with the fundamental rights particularly the one provided by article 17 (SC, 1988). The Court termed the freedom of association as one of the pillars of democracy. Moreover, it is through the exercise of this right that the citizens elect their representatives to from the government of the State. Therefore, the proper exercise of this right ultimately determines their fate which obviously has direct bearing on the society as a whole.

\section{Conclusion}

The above analysis of the various issues conclusively determines that the existing land tenure is not compatible with the fundamental rights and freedoms as provided by the Constitution and interpreted by the superior courts. It must be borne in mind that now-a-days the standard of civilization of States is often judged with their commitments to elevate the poor and depressed classes of the society. The only serious effort by the State to redress the grievances of the agricultural tenants and the poor labourers attached to the land was, perhaps, in the form of the promulgation of the land reform laws nearly half a century ago. However, after the verdict of the SAB in the Qazalbash Waqf case, the issue of land reforms has almost become a dead issue in spite of the dejected condition of a huge village community. It is high time that the State took some bold and serious steps to provide social justice and economic well-being to these poor people. It is particularly so since the fundamental law of the country guarantees them a number of rights in this regard. The institution of landlordism and feudalism must be abolished to introduce suitable land reforms which ensure a reasonable increase in the agricultural production and uplift all those attached to the land. One way of doing so is to introduce new land reform laws within the parameters of the judgment of the SAB in Qazalbash Waqf case as it permits prospective fixation of ceiling on voluntary acquisition of property. 


\section{References}

Qazalbash Waqf and others versus Chief Land Commissioner, Punjab, Lahore and others, PLD 1990 Supreme Court 99 [Shariat Appellate Bench].

These provisions included Paragraph 8 of the M.L.R. 115 of 1972 and Section 3 of the Act II of 1977.

See, for example, B. H. Baden Powell, Land Revenue and Tenure in British India (New York: Macmillan \& Co., 1894), Dr. Hareet Kumar Meena, "Land Tenure Systems in the late $18^{\text {th }}$ and 19th century in Colonial India," American International Journal of Research in Humanities, Arts and Social Sciences 9(1), December 2014-February 2015, Sulekh Chandra Gupta, Agrarian Relations and Early British Rule in India: A Case Study of Ceded and Conquered Provinces (Uttar Pradesh, 1801-1833) (London: Asia Publishing House, 1963).

Report of the Land Reforms Commission for West Pakistan, Lahore, 1959. "The Land Tenure Problem" in Land Reforms in Pakistan: A Historical Perspective, ed. Syed Nawab Haider Naqvi, Mahmood Hassan Khan and M. Ghaffar Chaudhry (Islamabad: Pakistan Institute of Development Economics, 1987). (Hereinafter referred as RLRC, 1959)

Government of Pakistan, National Planning Board. The First Five Year Plan:1955-1960. Karachi, December 1957. "Land Reforms" in Land Reforms in Pakistan: A Historical Perspective, ed. Syed Nawab Haider Naqvi, Mahmood Hassan Khan and M. Ghaffar Chaudhry (Islamabad: Pakistan Institute of Development Economics, 1987). (Hereinafter referred as FYP)

Note of Dissent authored by M. Masud, a member of the Hari Enquiry Committee is available at: https://www.masudkhaddarposhtrust.org/books-and-articles-bym-masud/HARI-REPORT-REPRINT-Final-June-2007-pdf (last accessed: 23.07.2017). (Hereinafter referred as Masud, 1949)

Report of the Agrarian Committee of the Pakistan Muslim League, 1949. "The Land Tenure Problem" in Land Reforms in Pakistan: A Historical Perspective, ed. Syed Nawab Haider Naqvi, Mahmood Hassan Khan and M. Ghaffar Chaudhry (Islamabad: Pakistan Institute of Development Economics, 1987). (Hereinafter referred as RAC, 1949)

Syed Shabbir Hussain Kazmi and others versus Government of Pakistan and others, 2006 PLC (C.S.) 49 [Federal Shariat Court]

Abdul Wahab and others versus HBL and others, 2013 SCMR 1383 [Supreme Court of Pakistan] 
Mian Muhammad Nawaz Sharif versus President of Pakistan and others, PLD 1993 Supreme Court 473 (Hereinafter referred as Nawaz Sharif, 1993)

Messrs Shaheen Cotton Mills, Lahore and anotherversus Federation of Pakistan, Ministry of Commerce through Secretary and another, PLD 2011 Lahore 120

Miss Benazir Bhutto versus Federation of Pakistan and another, PLD 1988 Supreme Court 416 (Hereinafter referred as Benazir, 1988)

Messers Shah Murad Sugar Mills Ltd. through Deputy General Manager and others versus Government of Sindh through Secretary Agriculture and Food Department, Sindh Secretariat, Karachi and others, 2003 CLC 1078 [Karachi] (Hereinafter referred as Shah Murad, 2003)

Mst. Margrate versus Executive District Officer Schools and Literacy Department, District Charsadda and 4 others, 2005 PLC (C.S.) 886

Qazi Akhtar Ali versus Director of Agriculture (Economics and Marketing) Punjab Agriculture House, Lahore and another, 2000 PLC (C.S.) 784 [Lahore High Court]

Zahid Ahmed versus Province of Sindh through Secretary to the Government of Sindh Education and Literacy Department, Karachi and 4 others, 2012 PLC (C.S.) 124 [Karachi]

Abdul Qadir versus District Education Officer (EE \& M), District Rahimyar Khan and other, 2001 PLC (C.S.) 1073 [Lahore High Court]

Ayaz Ahmed Memon versus Pakistan Railways, Ministry of Railway, Islamabad through Chairman and another, 2011 PLC (C.S.) 281 [Karachi]

Human Rights Commission of Pakistan and 2 others versus Government of Pakistan and others, PLD 2009 Supreme Court 507

Ikram Bari and others versus National Bank of Pakistan through President and others, 2005 PLC (C.S.) 915

Muhammad Umer Rathore versus Federation of Pakistan, 2009 CLD 257

Arshad Mehmood others versus Government of Punjab through Secretary Transport, Civil Secretariat, Lahore and others, PLD 2005 Supreme Court 193

Muhammad Asim and others versus Telecommunication and others, 1997 PLC (C.S.) 1131

Alleged Corruption in Rental Power Plants etc. Human Rights Cases No. 7734-G/2009, 1003-G/2010 and 56712/2010, 2012 SCMR 773

Muhammad Yasin versus Federation of Pakistan through Secretary Establishment Division, Islamabad and others, PLD 2012 Supreme Court 132 
Khawaja Muhammad Asif versus Federation of Pakistan and others, 2013 SCMR 1205

Ms. Shehla Zia and others versus Wapda, PLD 1994 Supreme Court 693

Workers' Party Pakistan through General Secretary and 6 others versus Federation of Pakistan and 2 others, PLD 2012 Supreme Court 681

Imran Khan and others versus Election Commission of Pakistan and others, PLD 2013 Supreme Court 120 